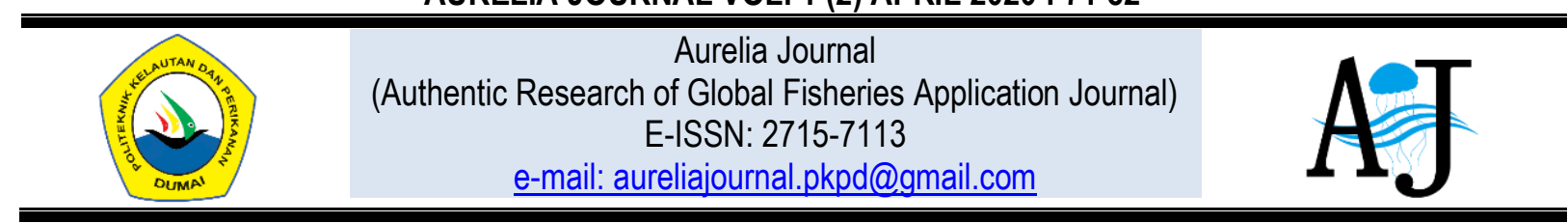

\title{
IDENTIFIKASI KOMODITAS UNGGULAN PERIKANAN DI KABUPATEN LOMBOK TIMUR
}

\section{IDENTIFICATION OF FISHERIES SUPERIOR COMMODITIES IN EAST LOMBOK DISTRICT}

\author{
Ratih Purnama Sari ${ }^{*}$, Soraya Gigentika², Tyas Dita Pramesthy ${ }^{1}$ \\ ${ }_{1}^{1}$ Program Studi Perikanan Tangkap, Politeknik Kelautan dan Perikanan Dumai \\ 2Program Studi IImu Kelautan, Fakultas Pertanian, Universitas Mataram \\ 2Forum IImiah Pengelolaan Perikanan Berkelanjutan Provinsi Nusa Tenggara Barat \\ *Korespondensi: ratihp.salim@gmail.com (RP Sari) \\ Diterima 12 Maret 2020 - Disetujui 25 Maret 2020
}

\begin{abstract}
ABSTRAK. Perairan di Provinsi Nusa Tenggara Barat (NTB) merupakan wilayah yang sangat potensial untuk pengembangan sektor perikanan tangkap karena perairan tersebut merupakan wilayah migrasi ikan. Potensi sumberdaya ikan yang tinggi di Kabupaten Lombok Timur seharusnya dapat dimanfaatkan secara optimal sehingga mendatangkan keuntungan bagi masyarakat nelayan disana. Strategi untuk mengoptimalkan pemanfaatan sumberdaya ikan yaitu dengan menentukan komoditas unggulannya. Metode analisis yang digunakan adalah location quotient (LQ) dan Indeks Spesialisasi (IS). Hasil yang diperoleh adalah ikan setuhuk hitam (Makaira indica), ikan tuna madidihang (Thunnus Albacares), ikan kenyar, ikan tetengkek (Megalaspis cordyla), ikan talang-talang (Scomberoides tala), dan ikan japuh (Dussumeiria spp) merupakan komoditas unggulan dan paling banyak dihasilkan di Kabupaten Lombok Timur, serta mampu menyumbang produksi perikanan di Provinsi NTB. Sedangkan komoditas spesial tidak dimiliki oleh kabupaten ini, namun masih terdapat komoditas yang potensial untuk dikembangkan, yaitu Ikan tuna madidihang (Thunnus Albacares), ikan cakalang (Katsuwonus pelamis), ikan setuhuk hitam (Makaira indica), ikan ekor kuning (Caesio erythrogaster), dan ikan tongkol (Euthynnus affinis).
\end{abstract}

KATA KUNCl: Komoditas Unggulan, Komoditas Unggulan Perikanan, Kabupaten Lombok Timur

ABSTRACT. West Nusa Tenggara's Waters is the potential regency to be developed in catch fisheries sector because it can be a migration area of fish. The highly potential resources in East Lombok District should be utilized optimally so that it gives profit. Strategy to optimize fisheries resources utilization is to figure out the superior commodity. The method used in this study is location Quotient (LQ) and Spesicialization Index (SI). The result of this study can be concluded that the superior commodities of East Lombok District are black marlin (Makaira indica), tuna (Thunnus albacares), hardtail jack (Megalaspis cordyla), talang queenfish (Scomberoides tala), rainbow sardines (Dussumeiria sp) which are more produced and being able to contribute fisheries production in West Nusa Tenggara Province. Whereas specialization commodities can not be determined in the regency, but stil have the potential commodities to be developed, such as tuna (Thunnus Albacares), skipjack tuna (Katsuwonus pelamis), black marlin (Makaira indica), yellowtail fish (Caesio erythrogaster), and tuna fish (Euthynnus affinis).

\section{KEYWORDS: Superior Commodity, Fisheries Superior Commodity, East Lombok Distric}

\section{Pendahuluan}

Provinsi Nusa Tenggara Barat (NTB) mempunyai potensi sumberdaya pesisir dan laut yang cukup tinggi. Luas perairan lautnya sekitar $29.159,04 \mathrm{~km}^{2}$, panjang pantainya sekitar $2.333 \mathrm{~km}$ dan perairan karangnya sekitar $3.601 \mathrm{~km}^{2}$. Provinsi NTB terdiri dari $10 \mathrm{kota} / \mathrm{kabupaten}$ yang terbagi dalam 
dua pulau, yaitu Pulau Lombok dan Pulau Sumbawa. Pulau Sumbawa terdiri dari lima kota/kabupaten, yaitu Kabupaten Sumbawa, Kabupaten Sumbawa Barat, Kabupaten Bima, Kabupaten Dompu, dan Kota Bima. Sedangkan Pulau Lombok terdiri dari lima kabupaten/kota, yaitu kabupaten Lombok Timur, Kabupaten Lombok Barat, Kabupaten Lombok Tengah, Kabupaten Lombok Utara, dan Kota Mataram. Tidak semua kabupaten/kota di daerah tersebut memiliki pelabuhan perikanan. Kabupaten Lombok Timur merupakan daerah yang memiliki pelabuhan perikanan dengan kelas tertinggi dibandingkan daerah lainnya di Provinsi NTB, yaitu Pelabuhan Perikanan Pantai (PPP) Labuhan Lombok.

Kabupaten Lombok Timur memiliki kontribusi yang besar dalam menghasilkan produksi perikanan. Data statistik perikanan tangkap Provinsi NTB Tahun 2013 menunjukkan bahwa 8,2\% produksi perikanan di Provinsi NTB berasal dari kabupaten tersebut. Secara geografis, wilayah Kabupaten Lombok Timur berbatasan langsung dengan Laut Jawa di bagian utara, Selat Alas di bagian timur, dan Samudera Hindia di bagian selatan. Oleh sebab itu, tidak heran jika dari sekitar 1 juta jiwa penduduk Kabupaten Lombok Timur, sebesar 19\% memiliki pekerjaan sebagai nelayan tradisional (Bachtiar, 2005). Selain itu, kondisi geografis Kabupaten Lombok Timur yang diapit oleh perairan menyebabkan Kabupaten Lombok Timur memiliki potensi sumberdaya ikan yang tinggi. Kabupaten Lombok Timur memiliki produksi perikanan tangkap sebesar 1.232 .000 ton pada tahun 2018 (BPS Kabupaten Lombok Timur, 2019).

Potensi sumberdaya ikan yang tinggi di Kabupaten Lombok Timur seharusnya dapat dimanfaatkan secara optimal sehingga mendatangkan keuntungan bagi masyarakat nelayan disana. Salah satu strategi untuk mengoptimalkan pemanfaatan sumberdaya ikan yaitu dengan menentukan komoditas unggulannya. Penentuan komoditas unggulan perikanan di Kabupaten Lombok Timur belum pernah dilakukan sebelumnya. Analisis komoditas unggulan bertujuan untuk mengetahui efisiensi pengelolaan sumberdaya perikanan.

Menurut Ridwan (2018), komoditas unggulan adalah suatu jenis komoditas yang paling diminati oleh masyarakat di suatu wilayah, bernilai jual tinggi, dan mampu memberikan pemasukan ekonomi dibandingkan jenis ikan lainnya. Sebagai tambahan, komoditas perikanan yang unggul juga memiliki kriteria jumlah produksi yang banyak dan tersedia sepanjang tahun dari seluruh komoditas perikanan di suatu pelabuhan perikanan (Sirait, 2013). Penelitian ini diharapkan dapat menjelaskan komoditas unggulan yang berpotensi untuk dikembangkan di Kabupaten Lombok Timur.

\section{Bahan dan Metode}

Data yang diambil dalam penelitian ini berupa data sekunder, yaitu data dari Dinas Kelautan dan Perikanan Provinsi NTB periode tahun 2009, 2010, 2011, dan tahun 2013. Data tersebut meliputi data produksi perikanan tangkap di Kabupaten Lombok Timur dan produksi perikanan di Provinsi Nusa Tenggara Barat. Analisis yang dipakai untuk menentukan komoditas unggulan di Kabupaten Lombok Timur adalah analisis LQ (Location Quotient) dan analisis Indeks Spesialisasi (IS).

\subsection{Analisis Location Quotient (LQ)}

Analisis LQ adalah indeks perbandingan produksi suatu jenis ikan tertentu di Kabupaten Lombok Timur terhadap total produksi jenis ikan tertentu di Provinsi NTB dengan total produksi ikan di Kabupaten Lombok Timur terhadap total produksi ikan di Provinsi NTB. Menurut pengertian lain, LQ digunakan untuk mengetahui sektor basis/potensial suatu wilayah tertentu (Daryanto \& Hufizrianda 2010). Formula yang digunakan adalah:

$$
\mathrm{LQ}=\frac{\frac{v i}{v t}}{\frac{V i}{V t}}
$$

Keterangan:

vi : Jumlah produksi ikan i di Kabupaten Lombok Timur

vt : Jumlah produksi ikan i di Provinsi NTB 
Vi $\quad$ : Total produksi seluruh jenis ikan di Kabupaten Lombok Timur

Vt : Total produksi seluruh jenis ikan di Provinsi NTB

Nilai $L Q>1$ menujukkan bahwa ikan jenis ke-i merupakan sektor basis dan memiliki daya saing tinggi. Nilai $L Q<1$ menujukkan bahwa ikan jenis ke-i bukan merupakan sektor basis, tidak memiliki daya saing, dan harus dipasok dari luar wilayah. Serta nilai $L Q=1$ menunjukkan bahwa jenis ikan ke-i bukan merupakan sektor basis, berdaya saing rendah dan hanya terdistribusi di wilayah lokal.

Pendekatan fokus produksi perikanan tangkap dengan $L Q$ dilakukan menggunakan 2 kategori yaitu nilai $L Q$ dan nilai pertumbuhan $L Q$. Kriteria scoring nilai $L Q$ adalah sebagai berikut:

a) Nilai $L Q$ diberi skor $=2$ jika $L Q>1$;

b) Nilai $L Q$ diberi skor $=1$ jika $L Q=1$;

c) Nilai $L Q$ diberi skor $=0$ jika $L Q<1$.

Penentuan skor pertumbuhan LQ akan dilakukan menurut kriteria sebagai berikut:

a) Jika pertumbuhan $L Q$ positif, maka diberi skor $=2$

b) Jika pertumbuhan $L Q$ tetap, maka diberi skor $=1$

c) Jika pertumbuhan $L Q$ negatif maka diberi skor $=0$

Nilai penjumlahan tertinggi pada hasil pembobotan LQ merupakan komoditas unggulan yang dijadikan prioritas di Kabupaten Lombok Timur.

\subsection{Indeks Spesialisasi (IS)}

Analisis Indeks Spesialisasi (IS) bertujuan untuk mengetahui spesialisasi produksi ikan di Kabupaten Lombok Timur terhadap jenis ikan tertentu. Sama halnya dengan metode yang dilakukan oleh Daryanto \& Hufizrianda (2010), Nilai IS diperoleh dengan tahapan:

a) Menghitung persentase jumlah produksi tiap jenis ikan di Kabupaten Lombok Timur terhadap total produksi;

b) Menghitung persentase jumlah produksi tiap jenis ikan di Provinsi NTB terhadap total produksinya;

c) Menghitung selisih antara nilai persentase pada tahap pertama dengan nilai persentase pada tahap kedua, selanjutnya nilai-nilai selisih yang bertanda positif dijumlahkan. Langkah terakhir yaitu total nilai tersebut dibagi dengan 100 untuk mendapatkan nilai IS.

Keputusan yang diambil dari perolehan nilai IS adalah semakin besar nilai IS, maka semakin tinggi spesialisasi komoditas di wilayah yang terkonsentrasi pada sektor-sektor dimana nilai selisih persentasenya positif. Hasil analisis LQ dan IS selanjutnya dikombinasikan untuk mengetahui komoditas unggulan di Kabupaten Lombok Timur yang dapat dikembangkan oleh lokasi tersebut.

\section{Hasil dan Pembahasan}

\subsection{Penetapan Komoditas Unggulan}

Berdasarkan hasil analisis $L Q$, diperoleh indeks yang dapat membandingkan peranan jenis ikan tertentu di Kabupaten Lombok Timur terhadap peranan jenis ikan di Provinsi NTB. Nilai LQ yang lebih besar dari 1 merupakan komoditas sektor basis dan memiliki daya saing tinggi dibandingkan komoditas lainnya. Nilai LQ produksi perikanan tangkap di Kabupaten Lombok Timur tahun 2009 - 2013 disajikan pada Tabel 1.

Tabel 1. Nilai Location Quotient (LQ) produksi perikanan tangkap Kabupaten Lombok Timur Tahun 2009, 2010, 2011, dan 2013

\begin{tabular}{|c|c|c|c|c|c|c|c|c|c|}
\hline \multirow{2}{*}{ NO } & \multirow{2}{*}{ JENIS IKAN Ke-i } & \multicolumn{8}{|c|}{ LQ } \\
\hline & & 2009 & Sektor & 2010 & Sektor & 2011 & Sektor & 2013 & Sektor \\
\hline 1 & Cendro & 1,4 & Basis & 4,0 & Basis & 3,1 & Basis & 2,6 & Basis \\
\hline 2 & $\begin{array}{l}\text { Ekor kuning/ } \\
\text { pisang }\end{array}$ & 2,6 & Basis & 1,3 & Basis & 2,7 & Basis & 4,2 & Basis \\
\hline
\end{tabular}




\begin{tabular}{|c|c|c|c|c|c|c|c|c|c|}
\hline \multirow{2}{*}{ NO } & \multirow{2}{*}{ JENIS IKAN Ke-i } & \multicolumn{8}{|c|}{ LQ } \\
\hline & & 2009 & Sektor & 2010 & Sektor & 2011 & Sektor & 2013 & Sektor \\
\hline 3 & Selar & 0,6 & $\begin{array}{l}\text { Non } \\
\text { basis }\end{array}$ & 0,3 & Non basis & 0,4 & $\begin{array}{l}\text { Non } \\
\text { basis }\end{array}$ & 0,2 & $\begin{array}{l}\text { Non } \\
\text { basis }\end{array}$ \\
\hline 4 & Kuwe & 0,1 & $\begin{array}{l}\text { Non } \\
\text { basis }\end{array}$ & 0,3 & Non basis & 0,4 & $\begin{array}{l}\text { Non } \\
\text { basis }\end{array}$ & 0,3 & $\begin{array}{l}\text { Non } \\
\text { basis }\end{array}$ \\
\hline 5 & Layang & 0,4 & $\begin{array}{l}\text { Non } \\
\text { basis }\end{array}$ & 0,2 & Non basis & 0,3 & $\begin{array}{l}\text { Non } \\
\text { basis }\end{array}$ & 1,1 & Basis \\
\hline 6 & Sunglir & 0,5 & $\begin{array}{l}\text { Non } \\
\text { basis }\end{array}$ & 0,8 & Non basis & 1,3 & Basis & 1,4 & Basis \\
\hline 7 & Tetengkek & 5,7 & Basis & 3,8 & Basis & 4,8 & Basis & 6,5 & Basis \\
\hline 8 & Ikan Bawal & 2,3 & Basis & 0,6 & Non basis & 1,5 & Basis & 0,2 & $\begin{array}{l}\text { Non } \\
\text { basis }\end{array}$ \\
\hline 9 & Daun bambu/ Talang-talang & 5,8 & Basis & 3,5 & Basis & 4,2 & Basis & 4,9 & Basis \\
\hline 10 & Bentong & 8,2 & Basis & - & Non basis & 2,4 & Basis & 1,8 & Basis \\
\hline 11 & Kakap putih & 0,3 & $\begin{array}{l}\text { Non } \\
\text { basis }\end{array}$ & 0,4 & Non basis & 0,3 & $\begin{array}{l}\text { Non } \\
\text { basis }\end{array}$ & 0,6 & $\begin{array}{l}\text { Non } \\
\text { basis }\end{array}$ \\
\hline 12 & Siro & 1,2 & Basis & 1,2 & Basis & 0,6 & $\begin{array}{l}\text { Non } \\
\text { basis }\end{array}$ & 0,2 & $\begin{array}{l}\text { Non } \\
\text { basis }\end{array}$ \\
\hline 13 & Japuh & 7,6 & Basis & 2,2 & Basis & 3,8 & Basis & 4,6 & Basis \\
\hline 14 & Tembang & 0,8 & $\begin{array}{l}\text { Non } \\
\text { basis }\end{array}$ & 0,5 & Non basis & 0,5 & $\begin{array}{l}\text { Non } \\
\text { basis }\end{array}$ & 0,4 & $\begin{array}{l}\text { Non } \\
\text { basis }\end{array}$ \\
\hline 15 & Lemuru & 0,8 & $\begin{array}{l}\text { Non } \\
\text { basis }\end{array}$ & 0,6 & Non basis & 0,5 & $\begin{array}{l}\text { Non } \\
\text { basis }\end{array}$ & 0,3 & $\begin{array}{l}\text { Non } \\
\text { basis }\end{array}$ \\
\hline 16 & Lemadang & 1,1 & Basis & 3,5 & Basis & 1,8 & Basis & 3,0 & Basis \\
\hline 17 & Teri & 1,3 & Basis & 1,0 & Basis & 0 & $\begin{array}{l}\text { Non } \\
\text { basis }\end{array}$ & 0 & $\begin{array}{l}\text { Non } \\
\text { basis }\end{array}$ \\
\hline 18 & Ikan terbang & 4,2 & Basis & 0,1 & Basis & 0,7 & $\begin{array}{l}\text { Non } \\
\text { basis }\end{array}$ & 0,7 & $\begin{array}{l}\text { Non } \\
\text { basis }\end{array}$ \\
\hline 19 & Julung-julung & 4,3 & Basis & 1,5 & Basis & 1,4 & Basis & 1,5 & Basis \\
\hline 20 & Gerot-gerot & 3,2 & Basis & 2,7 & Basis & 3,1 & Basis & 5,8 & Basis \\
\hline 21 & Ikan Layaran & 0,5 & $\begin{array}{l}\text { Non } \\
\text { basis }\end{array}$ & 0,6 & Non basis & 0 & $\begin{array}{l}\text { Non } \\
\text { basis }\end{array}$ & 0 & $\begin{array}{l}\text { Non } \\
\text { basis }\end{array}$ \\
\hline 22 & Setuhuk hitam & 9,5 & Basis & 7,2 & Basis & 7,6 & Basis & 10,4 & Basis \\
\hline 23 & Ikan pedang & 0 & $\begin{array}{l}\text { Non } \\
\text { basis }\end{array}$ & 0 & Non basis & 0 & $\begin{array}{l}\text { Non } \\
\text { basis }\end{array}$ & 11,9 & Basis \\
\hline 24 & Peperek & 0,3 & $\begin{array}{l}\text { Non } \\
\text { basis }\end{array}$ & 0,3 & Non basis & 0 & $\begin{array}{l}\text { Non } \\
\text { basis }\end{array}$ & 0,3 & $\begin{array}{l}\text { Non } \\
\text { basis }\end{array}$ \\
\hline 25 & Lencam & 0,2 & $\begin{array}{l}\text { Non } \\
\text { basis }\end{array}$ & 0 & Non basis & 0 & $\begin{array}{l}\text { Non } \\
\text { basis }\end{array}$ & 0 & $\begin{array}{l}\text { Non } \\
\text { basis }\end{array}$ \\
\hline 26 & Kakap merah/ Bambangan & 0,3 & $\begin{array}{l}\text { Non } \\
\text { basis }\end{array}$ & 0,4 & Non basis & 0,4 & $\begin{array}{l}\text { Non } \\
\text { basis }\end{array}$ & 0,5 & $\begin{array}{l}\text { Non } \\
\text { basis }\end{array}$ \\
\hline 27 & Belanak & 0,2 & $\begin{array}{l}\text { Non } \\
\text { basis }\end{array}$ & 0,2 & Non basis & 0,2 & $\begin{array}{l}\text { Non } \\
\text { basis }\end{array}$ & 0,2 & $\begin{array}{l}\text { Non } \\
\text { basis }\end{array}$ \\
\hline 28 & Biji nangka & 1,1 & Basis & 1,1 & Basis & 0,8 & $\begin{array}{l}\text { Non } \\
\text { basis }\end{array}$ & 0,6 & $\begin{array}{l}\text { Non } \\
\text { basis }\end{array}$ \\
\hline 29 & Kurisi & 0,2 & $\begin{array}{l}\text { Non } \\
\text { basis }\end{array}$ & 0,2 & Non basis & 0,2 & $\begin{array}{l}\text { Non } \\
\text { basis }\end{array}$ & 0,4 & $\begin{array}{l}\text { Non } \\
\text { basis }\end{array}$ \\
\hline 30 & Gulamah/Tigawaja & 1,3 & Basis & 1,4 & Basis & 1,3 & Basis & 0,8 & $\begin{array}{l}\text { Non } \\
\text { basis }\end{array}$ \\
\hline 31 & Tongkol & 1,1 & Basis & 1,1 & Basis & 0 & Basis & 0 & $\begin{array}{c}\text { Non } \\
\text { basis }\end{array}$ \\
\hline 32 & Cakalang & 3,2 & Basis & 2,3 & Basis & 2,1 & Basis & 2,8 & Basis \\
\hline 33 & Kembung & 0,3 & $\begin{array}{l}\text { Non } \\
\text { basis }\end{array}$ & 0,1 & Non basis & - & $\begin{array}{l}\text { Non } \\
\text { basis }\end{array}$ & 0,3 & $\begin{array}{l}\text { Non } \\
\text { basis }\end{array}$ \\
\hline
\end{tabular}


Aurelia Journal, Vol. 1 (2): 71-82

\begin{tabular}{|c|c|c|c|c|c|c|c|c|c|}
\hline \multirow{2}{*}{ NO } & \multirow{2}{*}{ JENIS IKAN Ke-i } & \multicolumn{8}{|c|}{ LQ } \\
\hline & & 2009 & Sektor & 2010 & Sektor & 2011 & Sektor & 2013 & Sektor \\
\hline 34 & Kenyar & 9,4 & Basis & - & Non basis & 7,4 & Basis & 4,9 & Basis \\
\hline 35 & Tenggiri & 0,1 & $\begin{array}{l}\text { Non } \\
\text { basis }\end{array}$ & 0,1 & Non basis & 0,1 & $\begin{array}{l}\text { Non } \\
\text { basis }\end{array}$ & 0,1 & $\begin{array}{l}\text { Non } \\
\text { basis }\end{array}$ \\
\hline 36 & Albakora & 0 & $\begin{array}{l}\text { Non } \\
\text { basis }\end{array}$ & 0 & Non basis & 0,7 & $\begin{array}{c}\text { Non } \\
\text { basis }\end{array}$ & - & $\begin{array}{l}\text { Non } \\
\text { basis }\end{array}$ \\
\hline 37 & Madidihang & 6,7 & Basis & 6,7 & Basis & 3,3 & Basis & 5,6 & Basis \\
\hline 38 & Tuna mata besar & 0 & $\begin{array}{l}\text { Non } \\
\text { basis }\end{array}$ & 0 & Non basis & 0,1 & $\begin{array}{l}\text { Non } \\
\text { basis }\end{array}$ & 0,1 & $\begin{array}{l}\text { Non } \\
\text { basis }\end{array}$ \\
\hline 39 & Ikan Kerapu & 0,2 & $\begin{array}{l}\text { Non } \\
\text { basis }\end{array}$ & 0,4 & Non basis & 0,1 & $\begin{array}{l}\text { Non } \\
\text { basis }\end{array}$ & 0,1 & $\begin{array}{l}\text { Non } \\
\text { basis }\end{array}$ \\
\hline 40 & Ikan beronang & 0,2 & $\begin{array}{l}\text { Non } \\
\text { basis }\end{array}$ & 0,3 & Non basis & 0,2 & $\begin{array}{l}\text { Non } \\
\text { basis }\end{array}$ & 0,3 & $\begin{array}{l}\text { Non } \\
\text { basis }\end{array}$ \\
\hline 41 & Alu-alu/Manggilala/Pucul & 3,0 & Basis & 2,6 & Basis & 6,7 & Basis & 2,2 & Basis \\
\hline 42 & Kerong-kerong & 2,3 & Basis & 1,4 & Basis & 2,6 & Basis & 3,7 & Basis \\
\hline 43 & Layur & 0,6 & $\begin{array}{l}\text { Non } \\
\text { basis }\end{array}$ & 0,3 & Non basis & 0,3 & $\begin{array}{l}\text { Non } \\
\text { basis }\end{array}$ & 0,4 & $\begin{array}{l}\text { Non } \\
\text { basis }\end{array}$ \\
\hline 44 & Ikan Cucut & 4,1 & Basis & 5,2 & Basis & 3,1 & Basis & 4,0 & Basis \\
\hline 45 & Ikan Pari & 3,5 & Basis & 1,6 & Basis & 0,8 & Basis & 3,4 & Basis \\
\hline 46 & Udang & 0,2 & $\begin{array}{l}\text { Non } \\
\text { basis }\end{array}$ & 0,3 & Non basis & 0,2 & $\begin{array}{l}\text { Non } \\
\text { basis }\end{array}$ & - & $\begin{array}{l}\text { Non } \\
\text { basis }\end{array}$ \\
\hline 47 & Kepiting & 0,2 & $\begin{array}{l}\text { Non } \\
\text { basis }\end{array}$ & 0,4 & Non basis & 0,2 & $\begin{array}{l}\text { Non } \\
\text { basis }\end{array}$ & 0,2 & $\begin{array}{l}\text { Non } \\
\text { basis }\end{array}$ \\
\hline 48 & Rajungan & 3,7 & Basis & 1,7 & Basis & 2,4 & Basis & 0,1 & $\begin{array}{l}\text { Non } \\
\text { basis }\end{array}$ \\
\hline 49 & Kerang darah & 0 & $\begin{array}{l}\text { Non } \\
\text { basis }\end{array}$ & 0 & Non basis & 0,1 & $\begin{array}{l}\text { Non } \\
\text { basis }\end{array}$ & 0,2 & $\begin{array}{c}\text { Non } \\
\text { basis }\end{array}$ \\
\hline 50 & Cumi-cumi & 0,3 & $\begin{array}{l}\text { Non } \\
\text { basis }\end{array}$ & 1,5 & Basis & 2,8 & Basis & 2,8 & Basis \\
\hline 51 & Sotong & 0,8 & $\begin{array}{l}\text { Non } \\
\text { basis }\end{array}$ & 1,4 & Basis & 1,1 & Basis & 0 & $\begin{array}{l}\text { Non } \\
\text { basis }\end{array}$ \\
\hline
\end{tabular}

Berdasarkan data pada Tabel 1, diketahui bahwa terdapat 51 jenis komoditas perikanan tangkap di Kabupaten Lombok Timur pada tahun 2009, 2010, 2011, dan 2013. Produksi perikanan tangkap di Kabupaten Lombok Timur berupa jenis ikan, udang, kepiting, kerang, cumi-cumi dan sejenisnya. Bila dilihat dari nilai LQ pada tahun 2009, terdapat 25 jenis komoditas yang merupakan basis di Kabupaten Lombok Timur (nilai LQ > 1) dan sisanya sebesar 26 jenis merupakan komoditas non basis.

Pada tahun 2010 dan 2011, jumlah komoditas basis Kabupaten Lombok Timur sebanyak 24 jenis dan sisanya sebanyak 27 jenis merupakan komoditas non basis. Sedangkan pada tahun 2013, jumlah komoditas basis di kabupaten ini berkurang menjadi 22 jenis dan komoditas non basis bertambah menjadi 29 jenis. Perubahan jumlah komoditas sektor basis dan non basis di Kabupaten Lombok Timur dari tahun 2009, 2010, 2011, dan 2013 terlihat tidak terlalu signifikan. Jika dilihat kembali pada Tabel 1, jenis komoditas sektor basis di kabupaten ini hampir sama pada tiap-tiap tahun. Jenis hasil tangkapan yang memiliki nilai LQ yang tinggi antara lain ikan setuhuk hitam (Makaira indica), ikan tuna madidihang (Thunnus Albacares), ikan kenyar, ikan tetengkek (Megalaspis cordyla), ikan talang-talang (Scomberoides tala), dan ikan japuh (Dussumeiria spp).

Perolehan nilai LQ yang tinggi dipengaruhi oleh produksi jenis ikan di Kabupaten Lombok Timur setiap tahun. Ikan setuhuk hitam, ikan tuna madidihang, ikan kenyar, ikan tetengkek, ikan talangtalang, dan ikan japuh merupakan jenis hasil tangkapan yang paling banyak dihasilkan di Kabupaten Lombok Timur dan mampu menyumbang produksi ikan di Provinsi NTB. Selain itu, terdapat beberapa spesies ikan yang memiliki daya jual tinggi. 
Analisis selanjutnya yang perlu dilakukan untuk mempertajam hasil analisis sebelumnya yaitu dengan menghitung pertumbuhan nilai LQ dari tahun 2009 sampai 2011. Komoditas yang dapat dikatakan unggul akan memberikan nilai pertumbuhan yang positif sehingga berpengaruh terhadap kontribusi pada sektor perikanan dari tahun 2009 - 2011. Analisis pertumbuhan LQ tidak dilakukan pada tahun 2013. Hal ini dikarenakan tidak tersedianya data statistik perikanan pada tahun 2012. Pertumbuhan LQ pada tahun 2013 dapat dihitung apabila tersedia data produksi perikanan tahun sebelumnya. Berdasarkan perhitungan nilai $L Q$, maka dapat ditentukan bahwa produksi perikanan yang dapat dihitung nilai pertumbuhan LQ-nya adalah sebanyak 25 jenis komoditas.

Tabel 2. Nilai pertumbuhan LQ Komoditas perikanan tangkap di Kabupaten Lombok Timur

\begin{tabular}{|c|c|c|c|c|c|c|c|c|c|}
\hline \multirow[b]{2}{*}{ NO } & \multirow[b]{2}{*}{ JENIS IKAN } & \multicolumn{3}{|c|}{ LQ } & \multirow[t]{2}{*}{ Rata-Rata } & \multicolumn{2}{|c|}{ Pertumbuhan } & \multirow{2}{*}{$\begin{array}{l}\text { Total } \\
\text { Growth }\end{array}$} & \multirow{2}{*}{$\begin{array}{c}\text { Skor } \\
\text { Pertumbuhan } \\
\text { LQ }\end{array}$} \\
\hline & & 2009 & 2010 & 2011 & & $2009-2010$ & $2010-2011$ & & \\
\hline 1 & Cendro & 1,35 & 3,98 & 3,11 & 2,82 & 2,63 & $-0,87$ & 1,76 & 2 \\
\hline 2 & $\begin{array}{l}\text { Ekor kuning/ } \\
\text { Pisang-pisang }\end{array}$ & 2,59 & 1,33 & 2,75 & 2,22 & $-1,26$ & 1,42 & 0,15 & 2 \\
\hline 3 & Tetengkek & 5,66 & 3,75 & 4,83 & 4,75 & $-1,91$ & 1,07 & $-0,84$ & 0 \\
\hline 4 & Ikan Bawal & 2,30 & 0,64 & 1,51 & 1,48 & $-1,66$ & 0,87 & $-0,79$ & 0 \\
\hline 5 & $\begin{array}{l}\text { Daun bambu/ Talang- } \\
\text { talang }\end{array}$ & 5,77 & 3,52 & 4,22 & 4,50 & $-2,26$ & 0,70 & $-1,56$ & 0 \\
\hline 6 & Bentong & 8,17 & 0,00 & 2,38 & 3,52 & $-8,17$ & 2,38 & $-5,78$ & 0 \\
\hline 7 & Siro & 1,23 & 1,25 & 0,63 & 1,04 & 0,02 & $-0,61$ & $-0,60$ & 0 \\
\hline 8 & Japuh & 7,63 & 2,16 & 3,80 & 4,53 & $-5,46$ & 1,64 & $-3,83$ & 0 \\
\hline 9 & Lemadang & 1,10 & 3,53 & 1,83 & 2,15 & 2,43 & $-1,70$ & 0,73 & 2 \\
\hline 10 & Ikan terbang & 4,23 & 0,12 & 0,75 & 1,70 & $-4,11$ & 0,63 & $-3,48$ & 0 \\
\hline 11 & Julung-julung & 4,26 & 1,48 & 1,37 & 2,37 & $-2,78$ & $-0,11$ & $-2,90$ & 0 \\
\hline 12 & Gerot-gerot & 3,25 & 2,71 & 3,08 & 3,01 & $-0,54$ & 0,36 & $-0,17$ & 0 \\
\hline 13 & Setuhuk hitam & 9,48 & 7,20 & 7,57 & 8,08 & $-2,29$ & 0,38 & $-1,91$ & 0 \\
\hline 14 & Biji nangka & 1,10 & 1,09 & 0,80 & 1,00 & $-0,02$ & $-0,29$ & $-0,31$ & 0 \\
\hline 15 & $\begin{array}{l}\text { Gulamah/ } \\
\text { Tigawaja }\end{array}$ & 1,25 & 1,37 & 1,31 & 1,31 & 0,11 & $-0,06$ & 0,06 & 2 \\
\hline 16 & Cakalang & 3,21 & 2,32 & 2,12 & 2,55 & $-0,89$ & $-0,20$ & $-1,09$ & 0 \\
\hline 17 & Kenyar & 9,41 & 0,00 & 7,37 & 5,59 & $-9,41$ & 7,37 & $-2,04$ & 0 \\
\hline 18 & Madidihang & 6,71 & 6,72 & 3,26 & 5,56 & 0,02 & $-3,47$ & $-3,45$ & 0 \\
\hline 19 & $\begin{array}{l}\text { Alu-alu/ } \\
\text { Manggilala/Pucul }\end{array}$ & 3,00 & 2,64 & 6,68 & 4,11 & $-0,37$ & 4,04 & 3,68 & 2 \\
\hline 20 & Kerong-kerong & 2,34 & 1,41 & 2,59 & 2,12 & $-0,93$ & 1,18 & 0,25 & 2 \\
\hline 21 & Ikan Cucut & 4,06 & 5,18 & 3,11 & 4,12 & 1,12 & $-2,08$ & $-0,96$ & 0 \\
\hline 22 & Ikan Pari & 3,50 & 1,65 & 0,82 & 1,99 & $-1,86$ & $-0,82$ & $-2,68$ & 0 \\
\hline 23 & Rajungan & 3,69 & 1,69 & 2,44 & 2,61 & $-2,00$ & 0,75 & $-1,25$ & 0 \\
\hline 24 & Cumi-cumi & 0,31 & 1,52 & 2,79 & 1,54 & 1,21 & 1,27 & 2,48 & 2 \\
\hline 25 & Sotong & 0,81 & 1,44 & 1,06 & 1,11 & 0,63 & $-0,38$ & 0,25 & 2 \\
\hline
\end{tabular}

Berdasarkan Tabel 2 diketahui bahwa dari 25 jenis komoditas unggulan yang diperhitungkan, hanya 8 jenis komoditas yang memiliki nilai pertumbuhan LQ positif. Pada Tabel 2 juga dapat dilihat bahwa jumlah komoditas unggulan periode tahun 2009-2010 yang memiliki nilai pertumbuhan LQ positif lebih sedikit dibandingkan periode tahun 2010-2011. Artinya produksi komoditas unggulan pada 
tahun 2009-2010 mengalami penurunan yang signifikan sehingga nilai pertumbuhan LQ-nya adalah negatif.

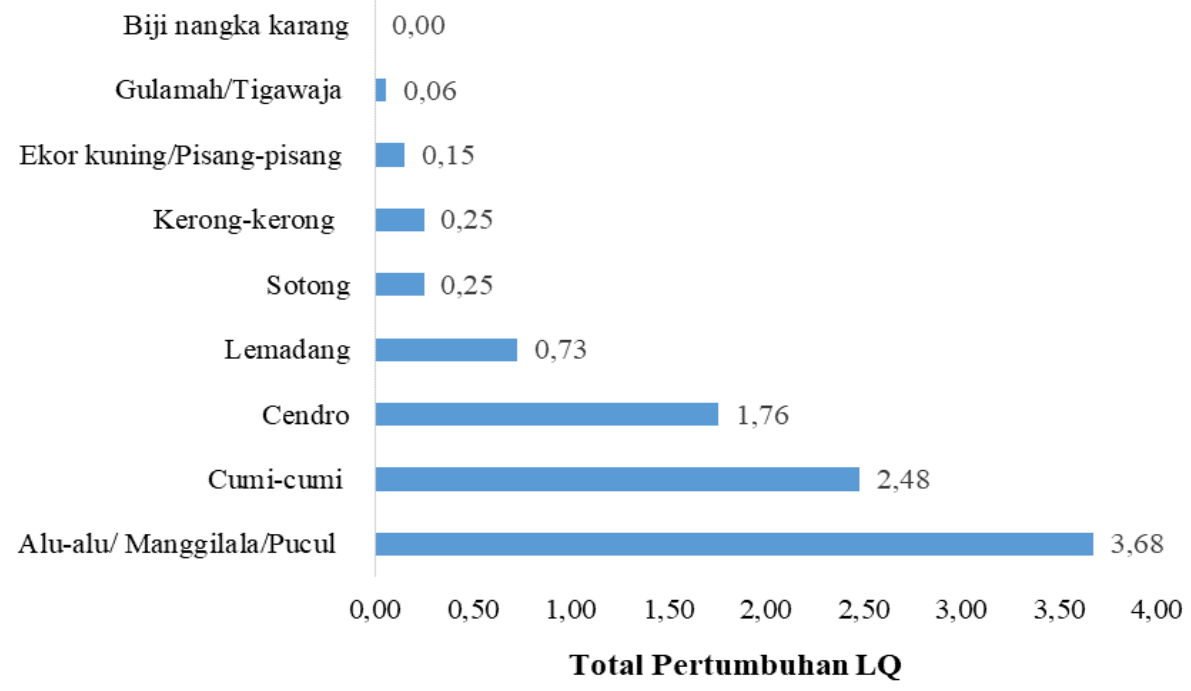

Gambar 1. Nilai Pertumbuhan LQ Komoditas Unggulan di Kabupaten Lombok Timur

Diagram pertumbuhan LQ dapat dilihat pada Gambar 1, dimana nilai paling tinggi terjadi pada jenis komoditas ikan alu-alu (Sphyraena) sebesar 3,68; cumi-cumi (Loligo edulis) sebesar 2,48; ikan cendro (Tylosurus crocodilus) sebesar 1,76; ikan lemadang sebesar 0,73; Sotong (Sepiida) sebesar 0,25; ikan kerong-kerong (Terapon jarbua) sebesar 0,25; ikan ekor kuning (Caesio erythrogaster) sebesar 0,15; dan ikan gulamah (Johnius trachycephalus) sebesar 0,05. Ikan-ikan tersebut merupakan komoditas yang paling tinggi jumlah produksinya dibandingkan dengan komoditas lainnya di Kabupaten Lombok Timur.

Perbedaan hasil analisis ini disebabkan karena perbedaan metode analisis data yang dilakukan. Analisis menggunakan Location Quotient (LQ) sangat bergantung pada besarnya volume produksi suatu komoditas (Kohar 2012). Sehingga komoditas yang memiliki nilai jual tinggi atau ekonomis penting tidak akan mempengaruhi kriteria komoditas unggulan apabila jumlah produksinya kecil.

Walaupun nilai pertumbuhan LQ telah diperoleh, tetapi masih perlu dilakukan perhitungan nilai keseluruhan skor dari masing-masing komoditas tiap tahun agar dapat ditentukan komoditas unggulan di Kabupaten Lombok Timur. Analisis selanjutnya adalah pemberian skor pertumbuhan LQ. Analisis ini masih dilakukan terhadap 25 jenis komoditas yang memiliki nilai $L Q>1$. Kriteria pemberian skor ini yaitu; bila nilai total pertumbuhan $L Q$ positif maka akan diberikan skor 2, sedangkan bila total pertumbuhan negatif maka akan diberikan skor 0 , dan bila pertumbuhannya tetap maka akan diberikan skor 1. Hasil pemberian bobot untuk setiap komoditas akan digunakan untuk menentukan jenis komoditas unggulan di Kabupaten Lombok Timur.

Tabel 3. Penentuan komoditas unggulan perikanan tangkap di Kabupaten Lombok Timur

\begin{tabular}{|c|c|c|c|c|c|c|c|}
\hline \multirow{2}{*}{ NO } & \multirow{2}{*}{ JENIS IKAN } & \multirow{2}{*}{$\begin{array}{l}\text { Total } \\
\text { Growth }\end{array}$} & \multirow{2}{*}{$\begin{array}{c}\text { Skor } \\
\text { Pertumbuhan } \\
\text { LQ }\end{array}$} & \multicolumn{3}{|c|}{ LQ } & \multirow{2}{*}{$\begin{array}{l}\text { Tota } \\
\text { Skor }\end{array}$} \\
\hline & & & & 2009 & 2010 & 2011 & \\
\hline 1 & Cendro & 1,76 & 2 & 2 & 2 & 2 & 8 \\
\hline 2 & $\begin{array}{l}\text { Ekor kuning/ Pisang- } \\
\text { pisang }\end{array}$ & 0,15 & 2 & 2 & 2 & 2 & 8 \\
\hline 3 & Lemadang & 0,73 & 2 & 2 & 2 & 2 & 8 \\
\hline 4 & Gulamah/ & 0,06 & 2 & 2 & 2 & 2 & 8 \\
\hline 5 & Alu-alu/Manggilala/Pucul & 3,68 & 2 & 2 & 2 & 2 & 8 \\
\hline
\end{tabular}


Aurelia Journal, Vol. 1 (2): 71-82

\begin{tabular}{|c|c|c|c|c|c|c|c|}
\hline \multirow{2}{*}{ NO } & \multirow{2}{*}{ JENIS IKAN } & \multirow{2}{*}{$\begin{array}{l}\text { Total } \\
\text { Growth }\end{array}$} & \multirow{2}{*}{$\begin{array}{c}\text { Skor } \\
\text { Pertumbuhan } \\
\text { LQ }\end{array}$} & \multicolumn{3}{|c|}{ LQ } & \multirow{2}{*}{$\begin{array}{l}\text { Total } \\
\text { Skor }\end{array}$} \\
\hline & & & & 2009 & 2010 & 2011 & \\
\hline 6 & Kerong-kerong & 0,25 & 2 & 2 & 2 & 2 & 8 \\
\hline 7 & Tetengkek & $-0,84$ & 0 & 2 & 2 & 2 & 6 \\
\hline 8 & Daun bambu/ Talang-talang & $-1,56$ & 0 & 2 & 2 & 2 & 6 \\
\hline 9 & Japuh & $-3,83$ & 0 & 2 & 2 & 2 & 6 \\
\hline 10 & Julung-julung & $-2,90$ & 0 & 2 & 2 & 2 & 6 \\
\hline 11 & Gerot-gerot & $-0,17$ & 0 & 2 & 2 & 2 & 6 \\
\hline 12 & Setuhuk hitam & $-1,91$ & 0 & 2 & 2 & 2 & 6 \\
\hline 13 & Cakalang & $-1,09$ & 0 & 2 & 2 & 2 & 6 \\
\hline 14 & Madidihang & $-3,45$ & 0 & 2 & 2 & 2 & 6 \\
\hline 15 & Ikan Cucut & $-0,96$ & 0 & 2 & 2 & 2 & 6 \\
\hline 16 & Rajungan & $-1,25$ & 0 & 2 & 2 & 2 & 6 \\
\hline 17 & Cumi-cumi & 2,48 & 2 & 0 & 2 & 2 & 6 \\
\hline 18 & Sotong & 0,25 & 2 & 0 & 2 & 2 & 6 \\
\hline 19 & Ikan Bawal & $-0,79$ & 0 & 2 & 0 & 2 & 4 \\
\hline 20 & Bentong & $-5,78$ & 0 & 2 & 0 & 2 & 4 \\
\hline 21 & Siro & $-0,60$ & 0 & 2 & 2 & 0 & 4 \\
\hline 22 & Kenyar & $-2,04$ & 0 & 2 & 0 & 2 & 4 \\
\hline 23 & Ikan Pari & $-2,68$ & 0 & 2 & 2 & 0 & 4 \\
\hline 24 & Ikan terbang & $-3,48$ & 0 & 2 & 0 & 0 & 2 \\
\hline 25 & Biji nangka karang & 0,00 & 1 & 0 & 0 & 0 & 1 \\
\hline
\end{tabular}

Berdasarkan hasil skor penilaian LQ dan skor pertumbuhan $L Q$ terhadap 25 jenis komoditas ikan basis di Kabupaten Lombok Timur (Tabel 3), maka dapat ditentukan jenis komoditas unggulannya menurut aspek produksi yaitu ikan cendro (Tylosurus crocodilus), ikan ekor kuning (Caesio erythrogaster), ikan lemadang (Coryphaena hippurus), ikan gulamah (Johnius trachycephalus), ikan alu-alu (Sphyraena), dan ikan kerong-kerong (Terapon jarbua). Sebanyak 6 jenis komoditas ini memiliki kontribusi terhadap produksi hasil tangkapan yang tinggi bila dibandingkan dengan ikan sejenisnya di Provinsi NTB.

Hasil penelitian yang berbeda ditunjukkan oleh Santoso (2015), tentang komoditas unggulan yang terdapat di wilayah pesisir Lombok Timur. Komoditas unggulan di pesisir wilayah pesisir Lombok Timur adalah cumi-cumi (Loligo edulis) yang menempati proporsi tertinggi dari seluruh hasil tangkapan, kemudian diikuti oleh ikan cakalang (Katsuwanus pelamis), ikan tongkol (Euthynnus sp), ikan kakap merah Lutjanus campechanus), dan ikan kerapu (Ephinephelus sp). Penilaian ini dianalisis berdasarkan metode seleksi 2 tahap. Tahapan pertama yaitu, melakukan input semua komoditas yang dianggap unggulan oleh responden/stakeholder. Tahapan kedua yaitu melakukan metode skoring terhadap seluruh komoditas dan disaring menjadi 5 komoditas unggulan.

\subsection{Indeks Spesialisasi}

Indeks spesialisasi digunakan untuk mengetahui seberapa besar dominansi dari setiap jenis komoditas terhadap produksi perikanan tangkap di Kabupaten Lombok Timur. Indeks Spesialisasi dapat melengkapi atau memperkuat hasil analisis LQ (Hidayat, 2017). Nilai IS yang tinggi menunjukkan bahwa komoditas tersebut memiliki dominansi yang tinggi terhadap produksi perikanan di Kabupaten Lombok Timur. Hasil analisis indeks spesialisasi dapat dilihat pada Tabel 4. 
Tabel 4. Nilai Indeks Spesialisasi (IS) produksi perikanan tangkap di Kabupaten Lombok Timur $2009-2011$

\begin{tabular}{|c|c|c|c|c|c|}
\hline \multirow{2}{*}{ NO } & \multirow{2}{*}{ JENIS IKAN } & \multicolumn{3}{|c|}{ SELISIH PERSENTASE KAB DENGAN PROV } & \multirow{2}{*}{ Nilai IS } \\
\hline & & 2009 & 2010 & 2011 & \\
\hline 1 & Madidihang & 9,72 & 15,39 & 7,94 & 0,33 \\
\hline 2 & Cakalang & 12,06 & 6,74 & 6,69 & 0,25 \\
\hline 3 & Setuhuk hitam & 1,90 & 10,46 & 0,99 & 0,13 \\
\hline 4 & Ekor kuning/ Pisang-pisang & 3,17 & 0,57 & 3,73 & 0,07 \\
\hline 5 & Tongkol & 1,28 & 0,88 & 3,62 & 0,06 \\
\hline 6 & Ikan Cucut & 2,84 & 4,94 & 1,29 & 0,04 \\
\hline 7 & Julung-julung & 2,35 & 0,86 & 0,53 & 0,04 \\
\hline 8 & Teri & 1,21 & $-0,14$ & 2,47 & 0,04 \\
\hline 9 & Kenyar & 1,88 & $-0,04$ & 1,63 & 0,04 \\
\hline 10 & Bentong & 1,85 & $-0,18$ & 0,70 & 0,03 \\
\hline 11 & Japuh & 1,30 & 0,53 & 0,67 & 0,03 \\
\hline 12 & Rajungan & 0,83 & 0,41 & 0,69 & 0,02 \\
\hline 13 & Cumi-cumi & $-2,41$ & 1,61 & 3,88 & 0,01 \\
\hline 14 & Cendro & 0,02 & 0,67 & 0,72 & 0,01 \\
\hline 15 & Alu-alu/Manggilala/Pucul & 0,51 & 0,33 & 0,65 & 0,01 \\
\hline 16 & Ikan Pari & 1,28 & 0,63 & $-0,18$ & 0,01 \\
\hline 17 & Tetengkek & 0,40 & 0,29 & 0,37 & 0,01 \\
\hline 18 & Ikan Bawal & 0,81 & $-0,15$ & 0,22 & 0,01 \\
\hline 19 & Lemadang & 0,02 & 0,82 & 0,14 & 0,01 \\
\hline 20 & Gerot-gerot & 0,64 & 0,42 & 0,55 & 0,01 \\
\hline 21 & Kerong-kerong & 0,20 & 0,07 & 0,30 & 0,01 \\
\hline 22 & Ikan terbang & 1,05 & $-0,44$ & $-0,15$ & 0,00 \\
\hline 23 & Daun bambu/ Talang-talang & 0,14 & 0,11 & 0,12 & 0,00 \\
\hline 24 & Gulamah/Tigawaja & 0,10 & 0,11 & 0,12 & 0,00 \\
\hline 25 & Siro & 0,08 & 0,07 & $-0,28$ & 0,00 \\
\hline 26 & Sunglir & $-0,19$ & $-0,07$ & 0,10 & 0,00 \\
\hline 27 & Tuna sirip biru selatan & 0,00 & 0,00 & 0,00 & 0,00 \\
\hline 28 & Kerang darah & $-0,02$ & $-0,05$ & $-0,06$ & 0,00 \\
\hline 29 & Ikan Layaran & $-0,24$ & $-0,11$ & 0,15 & 0,00 \\
\hline 30 & Kepiting & $-0,08$ & $-0,09$ & $-0,09$ & 0,00 \\
\hline 31 & Albakora & $-0,27$ & $-0,07$ & $-0,01$ & 0,00 \\
\hline 32 & Biji nangka karang & $-0,16$ & $-0,19$ & $-0,06$ & 0,00 \\
\hline 33 & Tuna mata besar & $-0,02$ & $-0,55$ & $-0,09$ & $-0,01$ \\
\hline 34 & Layur & $-0,25$ & $-0,62$ & $-0,89$ & $-0,01$ \\
\hline 35 & Udang & $-1,32$ & $-0,89$ & $-1,16$ & $-0,02$ \\
\hline 36 & Belanak & $-0,98$ & $-0,94$ & $-1,02$ & $-0,03$ \\
\hline 37 & Ikan beronang & $-0,98$ & $-0,79$ & $-1,34$ & $-0,03$ \\
\hline 38 & Kurisi & $-1,96$ & $-1,58$ & $-1,56$ & $-0,05$ \\
\hline 39 & Lemuru & $-0,95$ & $-2,03$ & $-2,20$ & $-0,05$ \\
\hline 40 & Tenggiri & $-1,76$ & $-1,96$ & $-1,77$ & $-0,05$ \\
\hline 41 & Kuwe & $-2,72$ & $-1,51$ & $-1,36$ & $-0,06$ \\
\hline
\end{tabular}


Aurelia Journal, Vol. 1 (2): 71-82

\begin{tabular}{|c|c|c|c|c|c|}
\hline \multirow{2}{*}{ NO } & \multirow{2}{*}{ JENIS IKAN } & \multicolumn{3}{|c|}{ SELISIH PERSENTASE KAB DENGAN PROV } & \multirow{2}{*}{ Nilai IS } \\
\hline & & 2009 & 2010 & 2011 & \\
\hline 42 & Peperek & $-2,03$ & $-2,09$ & $-1,55$ & $-0,06$ \\
\hline 43 & Selar & $-1,28$ & $-3,05$ & $-1,69$ & $-0,06$ \\
\hline 44 & Kakap putih & $-2,39$ & $-1,41$ & $-2,46$ & $-0,06$ \\
\hline 45 & Tembang & $-1,18$ & $-3,18$ & $-2,47$ & $-0,07$ \\
\hline 46 & Kakap merah/ Bambangan & $-3,45$ & $-2,49$ & $-2,15$ & $-0,08$ \\
\hline 47 & Lencam & $-3,41$ & $-2,45$ & $-2,58$ & $-0,08$ \\
\hline 48 & Ikan Kerapu & $-4,03$ & $-2,93$ & $-4,66$ & $-0,12$ \\
\hline 49 & Layang & $-4,84$ & $-6,89$ & $-5,52$ & $-0,17$ \\
\hline 50 & Kembung & $-6,79$ & $-7,00$ & $-5,38$ & $-0,19$ \\
\hline 51 & Sotong & $-0,07$ & 0,08 & 0,01 & 0,00 \\
\hline
\end{tabular}

Berdasarkan kriteria pengukuran Indeks Spesialisasi menurut Kim et al. (1995), dalam Hidayat (2017), bila nilai IS regional mendekati nol maka komoditas tersebut tidak memiliki spesialisasi di wilayahnya. Bila nilai IS mendekati 2, maka komoditas tersebut memiliki spesialisasi. Batas tengah antara angka nol dan dua adalah satu. Oleh karena itu nilai IS yang lebih besar dari satu dapat dianggap sebagai komoditas yang memiliki spesialisasi. Nilai IS yang ditunjukkan pada Tabel 4 tidak ada yang mendekati angka dua, sehingga dapat disimpulkan bahwa Kabupaten Lombok Timur tidak memiliki komoditas perikanan tangkap yang spesial.

Ikan tuna madidihang (Thunnus Albacares), ikan cakalang (Katsuwonus pelamis), ikan setuhuk hitam (Makaira indica), ikan ekor kuning (Caesio erythrogaster), dan ikan tongkol (Euthynnus affinis) merupakan 5 jenis komoditas yang memiliki nilai IS tertinggi di Kabupaten Lombok Timur. Hasil analisis nilai $L Q$ dan IS menghasilkan jenis komoditas unggulan yang berbeda. Nilai LQ yang tinggi tidak mempengaruhi nilai IS. Meskipun jenis hasil tangkapan di Kabupaten Lombok Timur merupakan komoditas basis, namun belum tentu hasil tangkapan tersebut merupakan komoditas spesial di Kabupaten Lombok Timur. Jika dilihat pada nilai IS tertinggi, maka jenis komoditas tersebut dapat dikatakan sebagai komoditas yang potensial untuk dikembangkan karena memiliki kecukupan sumberdaya yang tersedia.

\section{KESIMPULAN}

Berdasarkan hasil yang diperoleh, maka dapat ditarik kesimpulan sebagai berikut: 1) jenis hasil tangkapan yang memiliki nilai LQ yang tinggi antara lain ikan setuhuk hitam (Makaira indica), ikan tuna madidihang (Thunnus Albacares), ikan kenyar, ikan tetengkek (Megalaspis cordyla), ikan talang-talang (Scomberoides tala), dan ikan japuh (Dussumeiria spp). Ikan-ikan tersebut merupakan komoditas basis yang paling banyak dihasilkan di Kabupaten Lombok Timur dan mampu menyumbang produksi ikan di NTB; 2) jenis komoditas unggulan Kabupaten Lombok Timur berdasarakan skor pertumbuhan LQ yaitu ikan cendro (Tylosurus crocodilus), ikan ekor kuning (Caesio erythrogaster), ikan lemadang (Coryphaena hippurus), ikan gulamah (Johnius trachycephalus), ikan alu-alu (Sphyraena), dan ikan kerong-kerong (Terapon jarbua). Komoditas ini memiliki kontribusi terhadap produksi hasil tangkapan yang tinggi setiap tahun bila dibandingkan dengan ikan sejenisnya di Provinsi NTB; 3) ikan tuna madidihang (Thunnus Albacares), ikan cakalang (Katsuwonus pelamis), ikan setuhuk hitam (Makaira indica), ikan ekor kuning (Caesio erythrogaster), dan ikan tongkol (Euthynnus affinis) merupakan 5 jenis komoditas yang memiliki nilai IS tertinggi di Kabupaten Lombok Timur sehingga dapat dikatakan sebagai komoditas yang potensial untuk dikembangkan karena memiliki kecukupan sumberdaya yang tersedia dari aspek produksi. 


\section{Daftar Pustaka}

Badan Pusat Statistik Kabupaten Lombok Timur. (2019). Kabupaten Lombok Timur Dalam Angka. BPS Kabupaten Lombok Timur.

Bachtiar, I. (2005). Integrating formal and customary approaches to responsible fisheries: a case study of District Fisheries Services in Nusa Tenggara Barat Province, Lombok, Indonesia. Jurnal Fish for People 3 (2): 38-47.

Daryanto, A., \& Hafizrianda, Y. (2010). Model-model Kuantitaif untuk Perencanaan Pembangunan Ekonomi Daerah. Konsep dan Aplikasi. Bogor: IPB Press.

Dinas Kelautan dan Perikanan Provinsi Nusa Tenggara Barat. (2009). Statistik Perikanan Tangkap Provinsi Nusa Tenggara Barat. Pemerintah Daerah Provinsi Nusa Tenggara Barat. (tidak dipublikasikan)

Dinas Kelautan dan Perikanan Provinsi Nusa Tenggara Barat. (2010). Statistik Perikanan Tangkap Provinsi Nusa Tenggara Barat. Pemerintah Daerah Provinsi Nusa Tenggara Barat. (tidak dipublikasikan)

Dinas Kelautan dan Perikanan Provinsi Nusa Tenggara Barat. (2011). Statistik Perikanan Tangkap Provinsi Nusa Tenggara Barat. Pemerintah Daerah Provinsi Nusa Tenggara Barat. (tidak dipublikasikan)

Dinas Kelautan dan Perikanan Provinsi Nusa Tenggara Barat. (2011). Statistik Pengolahan dan pemasaran hasil perikanan Provinsi Nusa Tenggara Barat. (tidak dipublikasikan)

Dinas Kelautan dan Perikanan Provinsi Nusa Tenggara Barat. 2012. Statistik Perikanan Tangkap Provinsi Nusa Tenggara Barat. Pemerintah Daerah Provinsi Nusa Tenggara Barat. (tidak dipublikasikan)

Dinas Kelautan dan Perikanan Provinsi Nusa Tenggara Barat. 2013. Statistik Perikanan Tangkap Provinsi Nusa Tenggara Barat. Pemerintah Daerah Provinsi Nusa Tenggara Barat. (tidak dipublikasikan)

Gigentika, S., Nurani, T. W., Wisudo, S. H., \& Haluan, J. (2017). Sistem Pemanfaatan Ikan Tuna di Nusa Tenggara. Jurnal Marine Fisheries, 8(1), 25-37.

Hidayat, M., \& Darwin, R. (2017). Analisis Sektor Unggulan dalam Pengembangan Wilayah Kabupaten Kepualaun Meranti. Jurnal Media Trend, 12(2), 156-167.

Kohar, A., \& Paramartha, D. (2012). Analisis Komoditas Unggulan Perikanan Tangkap di Kabupaten Rembang. Jurnal Harpodon Borneo, 5(2), 161-171.

Merta, I. G. S., Iskandar, B., Bahar, S., Suwarso, Hariati, T., Sadhotomo, B., Atmaja, S. B., Wudianto., Badruddin, M., \& Sumiomo, B. (2004). Musim Penangkapan lkan di Indonesia. Depok: Penebar Swadaya

Ridwan, M., Kasmi, M., \& Putri, A. R. S. (2018). Penentuan Komoditas Unggulan Perikanan Laut Kabupaten Polewali Mandar Berdasarkan Data Statistik Tahun 2016. Jurnal IPTEKS PSP, 5(10), 98-105.

Santoso, D. (2015). Pengelolaan Perikanan Tangkap Berbasis Ikan Unggulan di Selat Alas Provinsi Nusa Tenggara Barat. Disertasi. Institut Pertanian Bogor.

Sirait, M. (2013). Kajian Pengembangan Perikanan Berbasis Komoditas Unggulan di Kabupaten Muna. Jurnal Kelautan, 6(2), 150-156.

Tarigan, Robinson. (2004). Ekonomi Regional. Jakarta: Ghalia Indonesia. 
